\title{
BMJ Open Impact of smoking status on the efficacy of inhaled corticosteroids in chronic obstructive pulmonary disease: a systematic review
}

\author{
Kimberley Sonnex (D) , Hanna Alleemudder, Roger Knaggs
}

To cite: Sonnex K, Alleemudder $\mathrm{H}$, Knaggs $\mathrm{R}$. Impact of smoking status on the efficacy of inhaled corticosteroids in chronic obstructive pulmonary disease: a systematic review. BMJ Open 2020;10:e037509. doi:10.1136/ bmjopen-2020-037509

- Prepublication history and additional material for this paper are available online. To view these files, please visit the journal online (http://dx.doi. org/10.1136/bmjopen-2020037509).

Received 06 February 2020 Revised 12 February 2020 Accepted 10 March 2020

\section{Check for updates}

(C) Author(s) (or their employer(s)) 2020. Re-use permitted under CC BY-NC. No commercial re-use. See rights and permissions. Published by BMJ.

School of Pharmacy, University of Nottingham, Nottingham, UK

Correspondence to Kimberley Sonnex; kimberley.sonnex@nottingham. ac.uk

\section{ABSTRACT}

Objectives Inhaled corticosteroids (ICS) reduce exacerbation rates and the decline in lung function in people with chronic obstructive pulmonary disease (COPD) There is evidence that smoking causes 'steroid resistance' and thus reduces the effect of ICS. This systematic review aimed to investigate the effect of smoking on efficacy of ICS in COPD in terms of lung function and exacerbation rates.

\section{Design Systematic review.}

Data sources An electronic database search of PubMed, Ovid MEDLINE, Ovid Embase and Cochrane Library (January 2000 to January 2020).

Eligibility criteria Fully published randomised controlled trials (RCTs), in the English language, evaluating the use of ICS in COPD adults that stratified the participants by smoking status. Trials that included participants with asthma, lung cancer and pneumonia were excluded. The primary outcome measures were changes in lung function and yearly exacerbation rates.

Data extraction and synthesis Two independent reviewers extracted data and assessed risk of bias using the Cochrane Collaboration's tool.

Results Seven studies were identified. Four trials (17 892 participants) recorded change in forced expiratory volume in one second $\left(\mathrm{FEV}_{1}\right)$ from baseline to up to 30 months after starting treatment. Heavier smokers ( $>36$ pack years) using ICS had a greater decline in $\mathrm{FEV}_{1}$ that ranged from $-22 \mathrm{~mL}$ to $-75 \mathrm{~mL}$ in comparison to lighter smokers. Smokers using ICS had mixed results in $\mathrm{FEV}_{1}$ change: $-8 \mathrm{~mL}$ to $+77 \mathrm{~mL}$ in comparison to ex-smokers. Four trials (21 270 participants) recorded difference in COPD exacerbation rates at 52 weeks. The rate ratios favoured more exacerbations in ICS users who were current or heavier smokers than those who were ex-smokers or lighter smokers ( 0.81 to 0.99 vs 0.92 to 1.29 ).

Conclusions In COPD, heavier or current smokers do not gain the same benefit from ICS use on lung function and exacerbation rates as lighter or ex-smokers do, however effects may not be clinically important.

\section{PROSPERO registration number CRD42019121833}

\section{INTRODUCTION}

Cigarette smoking is a causative factor in chronic obstructive pulmonary disease (COPD) and it is estimated that worldwide,
Strengths and limitations of this study

- Patient-orientated outcomes were recorded at up to 30 months, making results applicable to practice.

- Two of the included trials are post hoc analyses of the same original trial. The original trial recruited few participants making it unreliable.

- The trials were heterogeneous in terms of classification of smoking status and outcome measures, making direct comparison difficult and unable to undertake meta-analysis.

- There was limited reporting of statistical analysis in the original trials and difficulty extracting all relevant data, making the reliability of results unknown.

around $80 \%$ of people with COPD are current or ex-smokers. ${ }^{12}$ In addition to contributing to an increased rate of lung function decline, recently it has been postulated that smoking may cause resistance to some drug treatments; most notably inhaled corticosteroids (ICS) ${ }^{34}$ Asthmatic patients who smoke often require higher doses of ICS for control of their disease. ${ }^{5}$ The mechanism for this resistance has yet to be fully established.

ICS reduce exacerbation rates and possibly reduce the decline in lung function, as measured by forced expiratory volume in one second $\left(\mathrm{FEV}_{1}\right)$, in comparison to placebo for people with COPD. ${ }^{67}$ As a result, ICS have been a mainstay of COPD treatment for some time. However, there has been some controversy around the use of ICS; most notably that not all people with COPD benefit from their use, ${ }^{89}$ and the vast array of adverse effects that long-term use of these medicines cause. It is well-established that ICS are highly effective anti-inflammatory agents in asthma yet efficacy in COPD, even at high doses, remains debated. The reasons for this are likely to be complex and multifactorial, however resistance to ICS due to smoking is one possible factor. 
One of the mechanisms by which ICS suppress inflammation in COPD is by acting on histone deacetylase-2 (HDAC-2) to inhibit the release of inflammatory mediators such as tumour necrosis factor alpha and interleukin-8 that activate inflammatory cells. ${ }^{10}$ Several animal models and in vitro studies have shown that cigarette smoke reduces the activity and expression of HDAC-2 in alveolar macrophages by imposing an oxidative stress in the lungs. ${ }^{11}$ Cigarette smoke contains several reactive oxygen species (ROS) and other noxious particles which generate ROS. Cigarette smoke also contains nitric oxide which combines with ROS to generate peroxynitrite. In mice exposed to cigarette smoke, peroxynitrite causes the nitration of HDAC-2, which consequently leads to a loss in HDAC-2 function. ${ }^{11}$ This reduction in levels and function of HDAC-2 prevent ICS from exerting the anti-inflammatory effect, thereby causing steroid resistance. ${ }^{12}$

It is not yet clear if smoking cessation reduces steroid resistance; it was noted that airway mucosal inflammation may persist even after smoking cessation. ${ }^{13}$ However there are many other benefits that smoking cessation brings on disease control in COPD; including reduced disease progression and reduced exacerbation rates. ${ }^{3}$ One small study found that there may even be a small element of steroid resistance caused by direct interaction of environmental tobacco smoke and aerosolised corticosteroid particles; which may alter drug deposition in the lungs and a subsequent decline in steroid efficacy. ${ }^{14}$

While there remains cellular observation of the resistance to ICS in smokers with COPD, as yet the clinical significance on patient outcomes, such as lung function and exacerbation rates, is still to be fully investigated; no systematic review of the evidence has been published.

\section{METHODS}

This systematic review was registered with PROSPERO (https://www.crd.york.ac.uk/prospero/). In addition, the full search strategy can be found in the online supplementary information.

\section{Literature search}

This systematic review was conducted by an electronic database search in PubMed (January 2000 to January 2020), Ovid MEDLINE (January 2000 to January 2020), Ovid Embase (January 2000 to January 2020) and Cochrane Library (January 2000 to January 2020). A structured search strategy including free text and Medical Subject Headings terms related to randomised controlled trial, COPD, smoking and inhaled corticosteroids (budesonide, fluticasone, ciclesonide, mometasone and beclometasone) was used to retrieve literature for this systematic review. The reference lists of the retrieved papers were also searched to identify further relevant studies.

\section{Inclusion criteria}

Fully published randomised controlled trials (RCTs) evaluating the use of ICS in COPD adults that stratified the participants by smoking status were included. Review articles, abstracts, papers which are not fully published or published in languages other than English were not included. Retrieved trials that included COPD patients with asthma, lung cancer and pneumonia were also excluded. Trials that did not stratify participants by smoking status or smoking pack-years were also excluded.

\section{Data extraction}

Information about the study characteristics which include the study design and length, settings, participants' age, diagnostic criteria for COPD, severity of COPD, ICS type, dose and frequency, duration of the intervention and frequency of follow-up were extracted. An estimated effect of ICS on the outcomes reported was calculated for each participant subgroup. The outcome measures were: difference in mean change of lung function between subgroups, as measured by $\mathrm{FEV}_{1}$, and rate ratio of yearly exacerbations.

\section{Quality assessment}

Risk of bias and quality assessment of all included studies was assessed using the Cochrane Collaboration tool for assessing risk. Where disagreement occurred, this was discussed and a consensus reached. Information extraction was completed by one researcher and confirmed by a second.

\section{PATIENT AND PUBLIC INVOLVEMENT}

No patient involved.

\section{RESULTS}

Seven RCTs were identified for inclusion in this systematic review (figure 1). Two further studies were identified as being potentially suitable: Bafadhel et al and Hoonhorst et al. ${ }^{16}$ The data in Bafadhel et al was not presented in a way that could be extracted for this systematic review and it's results are discussed separately. On closer inspection the analysis in Hoonhorst et al was a post hoc analysis of the Groningen Leiden Universities Corticosteroids in Obstructive Lung Disease (GLUCOLD) trial, the same as the study by Snoeck-Stroband et al. ${ }^{17}{ }^{18}$ It was not clear if the same patient group was analysed in both studies, and as the Hoonhorst study was methodologically flawed in terms of powering of the study, it has not been included. Additionally, Hinds et al and Pascoe et al reported secondary analysis of the FLAME and IMPACT studies respectively; ${ }^{19} 20$ it is uncertain if these were prespecified or not. Bhatt et al was a prespecified secondary analysis of the SUMMIT study. ${ }^{21}$

The seven RCTs included in this systematic review were heterogeneous in nature with respect to their stratification of smokers, study drug used and outcomes. 
Potentially relevant studies identified from search strategy $(n=162)$

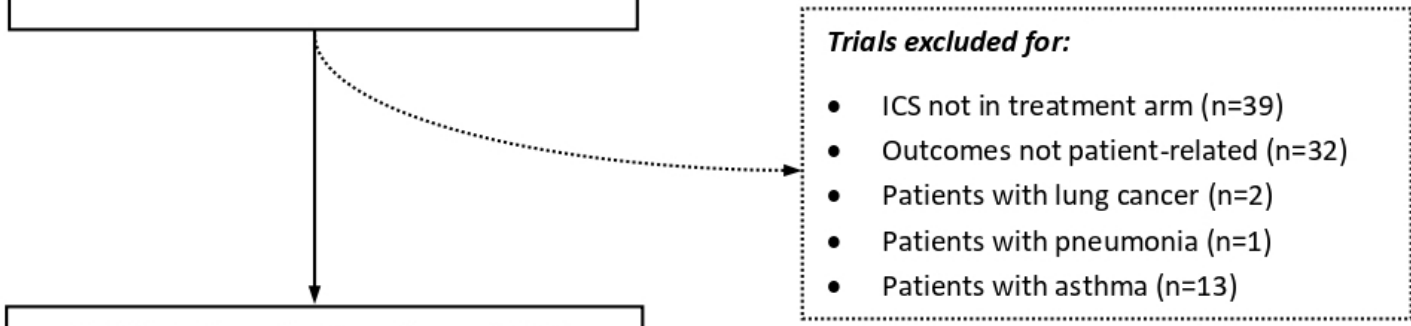

Eligible trials evaluating efficacy of ICS in COPD ( $N=75)$

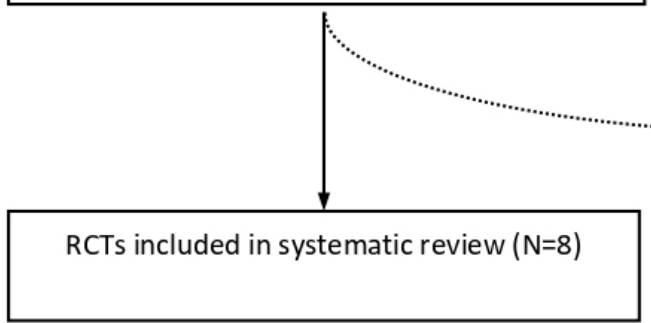

Trials excluded for:

- Studies which did not stratify participants according to smoking status $(n=66)$

- $\quad \operatorname{Non-RCT}(n=1)$

Figure 1 Exclusion of studies identified in the search strategy. COPD, chronic obstructive pulmonary disease; ICS, inhaled corticosteroids; RCT, randomised controlled trial.

Stratification of smokers broadly fell into two categories: current smoker versus ex-smoker in four studies ${ }^{1921-23}$ or heavier smoker versus lighter smoker in the remaining studies. ${ }^{182024}$ The study drugs used were either budesonide or fluticasone (propionate/furoate); five studies used fluticasone in combination with a long-actingbeta agonist (LABA), either salmeterol ${ }^{182223}$ or vilanterol, ${ }^{19-21}$ and the remaining two used fluticasone ${ }^{18}$ or budesonide alone. ${ }^{24}$ The outcomes reported were either change in lung function (measured by $\mathrm{FEV}_{1}$ ) in four studies, ${ }^{18} 212224$ or yearly exacerbation rates in four studies ${ }^{19-21} 23$ (one study reported both). Where lung function was reported, there were differences in the way in which $\mathrm{FEV}_{1}$ was measured; Pauwels et al reported median of the post-bronchodilator $\mathrm{FEV}_{1}$ slope (mL/year), Bhatt et al and Snoeck-Stroband et al reported post-bronchodilator $\mathrm{FEV}_{1}$ and Zheng et al reported pre-bronchodilator $\mathrm{FEV}_{1}$. There were also minor differences in patient characteristics, disease severity and study length. All of the included studies were parallel group, double-blind and placebo-controlled RCTs. A summary of the characteristics of the trials is reported in table 1 .

\section{Effect on lung function}

In total, 17892 participants were included in the trials reporting lung function as the outcome. Bhatt et al was by far the largest trial with over 16000 participants. The number of participants enrolled in each trial and general trial characteristics are shown in table 1. All four trials were funded by pharmaceutical companies.

There were a variety of primary outcomes reported, including: change in median post-bronchodilator $\mathrm{FEV}_{1}$ over time, inflammatory cell counts and mean prebronchodilator $\mathrm{FEV}_{1}$ Follow-up was carried out at least every 3 months. The changes in post-bronchodilator $\mathrm{FEV}_{1}$ in each study (except Zheng et al where pre-bronchodilator $\mathrm{FEV}_{1}$ is reported) are summarised in table 2. Although each study used the same measurement of lung function $\left(\mathrm{FEV}_{1}\right)$, it was represented as either: mean $(\mathrm{mL})$, median slope $(\mathrm{mL} /$ year) or interquartile median $(\mathrm{mL})$. The pre-bronchodilator $\mathrm{FEV}_{1}$ is reported for Zheng et al as the authors did not stratify post-bronchodilator $\mathrm{FEV}_{1}$ by smoking status. In addition to differences in outcome measure, the lack of data on number of participants in each smoking arm in some trials ${ }^{1824}$ means that no metaanalysis between the study results was possible.

The overall effect of smoking on the efficacy of ICS is summarised in table 2 . In studies where participants were categorised by pack-year history, ${ }^{1824}$ heavier smokers using ICS had a greater deterioration in $\mathrm{FEV}_{1}$ in comparison to lighter smokers using ICS. This ranged from $-22 \mathrm{~mL} /$ year to $-75 \mathrm{~mL} /$ year. However, when categorised by smoking status $^{2122}$ there were mixed results: current smokers' $\mathrm{FEV}_{1}$ ranged from $-8 \mathrm{~mL}$ to $+77 \mathrm{~mL}$ over the study period in comparison to ex-smokers or never-smokers; no statistical significance was reported with these results.

\section{Effect on exacerbation rate}

Three trials, Wedzicha (2016), Hinds (2015) and Pascoe (2019), evaluated the rate ratio of yearly COPD exacerbations at 52 weeks in comparison to the alternative treatment arm and one, Bhatt (2018), the percentage change in exacerbations, as indicated in (table 3$).^{19-2123}$ Hinds et al was a post hoc cluster analysis of the Effect of 


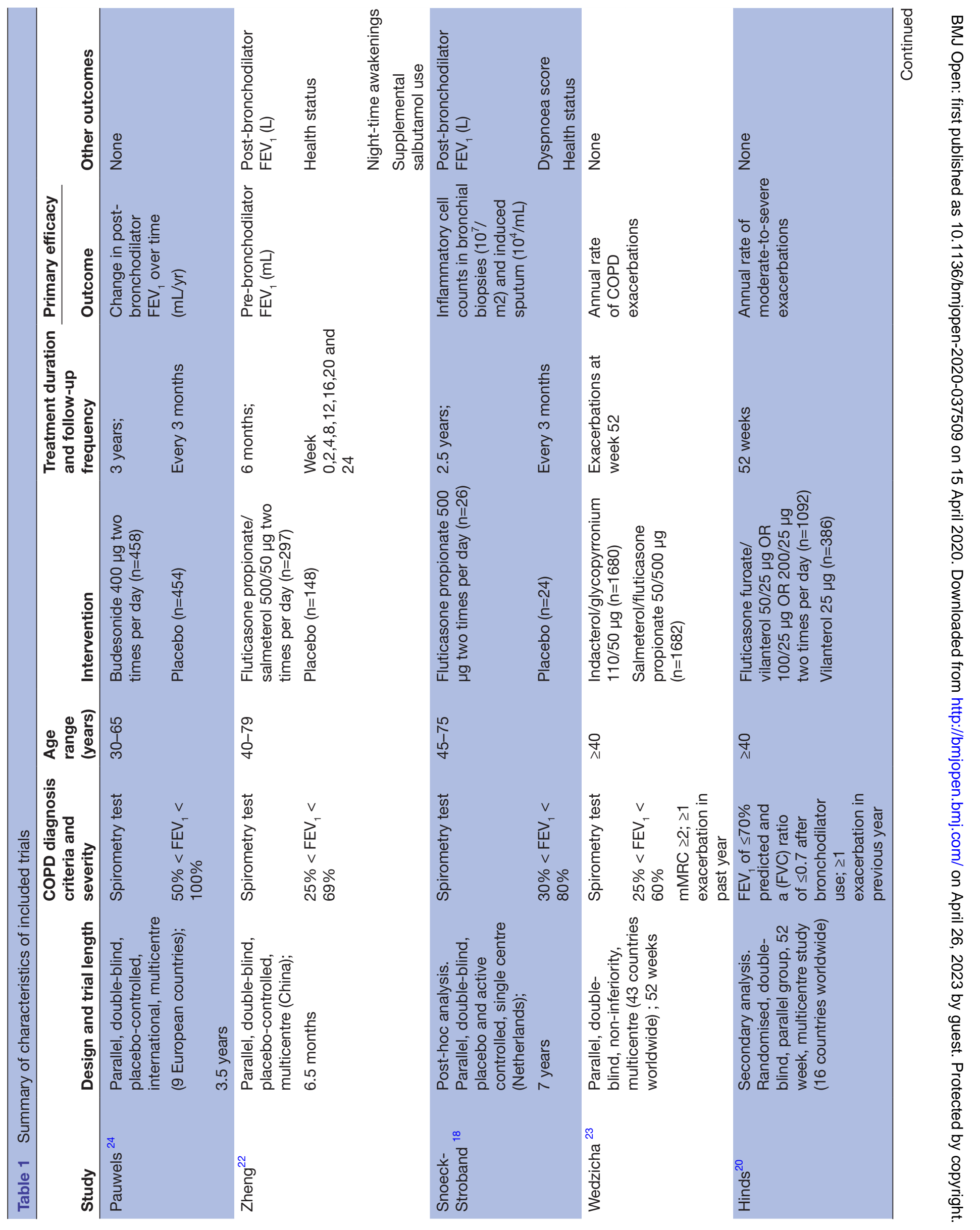




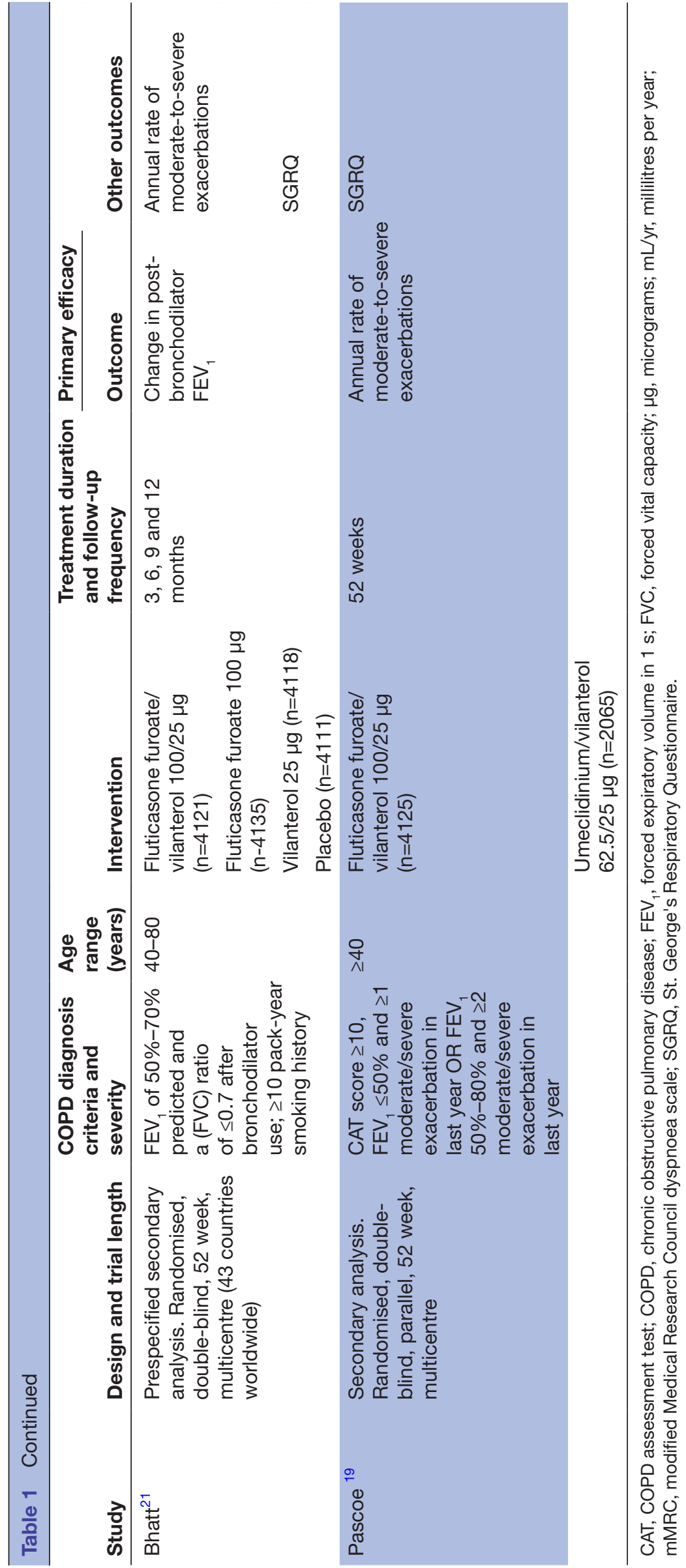


Table 2 Effect of ICS on FEV categorised by smoking status

\begin{tabular}{|c|c|c|c|c|c|c|c|c|}
\hline \multirow[b]{2}{*}{ Period } & \multirow[b]{2}{*}{ Study } & \multirow[b]{2}{*}{ Smoking status } & \multicolumn{2}{|c|}{ Change in $\mathrm{FEV}_{1}{ }^{*}$} & \multirow{2}{*}{$\begin{array}{l}\text { Estimated } \\
\text { effect of } \\
\text { ICS on FEV }_{1} \\
\text { outcomes }^{*}\end{array}$} & \multirow[b]{2}{*}{$P$ value } & \multirow{2}{*}{$\begin{array}{l}\text { Estimated effect } \\
\text { of smoking on } \\
\text { FEV } \text { outcomes } \\
\text { in ICS users* }\end{array}$} & \multirow[b]{2}{*}{$P$ value } \\
\hline & & & ICS & Placebo & & & & \\
\hline \multicolumn{9}{|c|}{ Smoking: pack-year history } \\
\hline \multirow[t]{2}{*}{$0-6$ months } & Pauwels & $\begin{array}{l}\text { Subjects with } \leq 36 \\
\text { pack-year history } \dagger\end{array}$ & 30 & -90 & 120 & $<0.001$ & -50 & $\ddagger$ \\
\hline & & $\begin{array}{l}\text { Subjects with }>36 \\
\text { pack-year history }\end{array}$ & 0 & -70 & 70 & 0.57 & & \\
\hline \multirow[t]{2}{*}{$\begin{array}{l}9-36 \\
\text { months }\end{array}$} & Pauwels & $\begin{array}{l}\text { Subjects with } \leq 36 \\
\text { pack-year history } \dagger\end{array}$ & -47 & -71 & 24 & 0.08 & 22 & $\ddagger$ \\
\hline & & $\begin{array}{l}\text { Subjects with }>36 \\
\text { pack-year history } \dagger\end{array}$ & -67 & -65 & -2 & 0.65 & & \\
\hline \multirow[t]{2}{*}{$\begin{array}{l}0-30 \\
\text { months }\end{array}$} & $\begin{array}{l}\text { Snoeck- } \\
\text { Stroband }\end{array}$ & $\begin{array}{l}\text { Subjects with } \geq 42 \\
\text { pack years } \dagger\end{array}$ & -28 & -63 & 35 & 0.242 & -75 & 0.023 \\
\hline & & $\begin{array}{l}\text { Subjects with }<42 \\
\text { pack years } \dagger\end{array}$ & 18 & -92 & 110 & 0.037 & & \\
\hline \multicolumn{9}{|c|}{ Smoking: smoking status } \\
\hline \multirow[t]{3}{*}{ 0-6 months } & Zheng & $\begin{array}{l}\text { Never-smoked } \\
(n=52)\end{array}$ & 261 & 141 & 120 & 0.3592 & - & - \\
\hline & & Ex-smokers $(n=297)$ & 177 & 6 & 171 & 0.0068 & 51 & $\ddagger$ \\
\hline & & $\begin{array}{l}\text { Current smokers } \\
(n=96)\end{array}$ & 112 & -85 & 197 & 0.0022 & 0.337662338 & $\ddagger$ \\
\hline \multirow{2}{*}{$\begin{array}{l}0-12 \\
\text { months }\end{array}$} & Bhatt & Smokers $(n=7678)$ & - & - & 22 & 0.038 & - & - \\
\hline & & $\begin{array}{l}\text { Ex-smokers } \\
(\mathrm{n}=8807)\end{array}$ & - & - & 30 & 0.005 & 8 & $\ddagger$ \\
\hline
\end{tabular}

${ }^{*}$ Change in FEV 1 reported. Values are in $\mathrm{mL}$, except for Pauwels (1999) and Snoeck-Stroband (2015) data are expressed as $\mathrm{mL} / \mathrm{year}$. $\dagger$ Number of participants in each study group not reported.

$\ddagger \mathrm{P}$ value cannot be calculated from data.

$\mathrm{FEV}_{1}$, forced expiratory volume in $1 \mathrm{~s}$; ICS, inhaled corticosteroids.

Indacaterol/Glycopyrronium vs Fluticasone propionate/ Salmeterol on COPD Exacerbations (FLAME) trial where the participants were sorted into clusters, the cluster of participants included in this systematic review had eosinophil counts of $\leq 2.4 \%$ and treatment was with either fluticasone propionate/salmeterol (ICS/LABA) or indacterol/glycopyrronium (LABA/long-actingmuscarinic antagonist, LAMA). ${ }^{25}$ Wedzicha et al, Bhatt et al and Pascoe

Table 3 Effects of ICS on yearly exacerbation

\begin{tabular}{|c|c|c|c|c|c|c|}
\hline \multirow[b]{2}{*}{ Period } & \multirow[b]{2}{*}{ Study } & \multicolumn{3}{|l|}{ Yearly exacerbations (95\% Cl) } & \multirow{2}{*}{$\begin{array}{l}\text { Rate } \\
\text { ratio* }\end{array}$} & \multirow[b]{2}{*}{$95 \%$} \\
\hline & & & ICS & Alternative & & \\
\hline $\begin{array}{l}0-52 \\
\text { weeks }\end{array}$ & Wedzicha & Current smoker ( $\mathrm{n}=658$ to 647 ) & - & - & 0.83 & 0.74 to 0.92 \\
\hline \multirow{2}{*}{$\begin{array}{l}0-52 \\
\text { weeks }\end{array}$} & \multirow[t]{2}{*}{ Pascoe } & Current smoker ( $n=1421$ to 726 ) & - & - & 0.99 & 0.87 to 1.12 \\
\hline & & Ex-smoker $(n=2704$ to 1339$)$ & - & - & 1.2 & 1.10 to 1.33 \\
\hline $\begin{array}{l}0-52 \\
\text { weeks }\end{array}$ & Bhatt & Ex-smoker $(n=8807)$ & - & - & $36 \% \dagger$ & $27 \%$ to $43 \%$ \\
\hline \multirow{2}{*}{$\begin{array}{l}0-52 \\
\text { weeks }\end{array}$} & \multirow[t]{2}{*}{ Hinds } & $>46$ pack years $(n=587)$ & 1.62 (1.29 to 2.02$)$ & $1.32(1.00$ to 1.76$)$ & 0.81 & 0.63 to 1.06 \\
\hline & & $\leq 46$ pack years $(n=891)$ & $0.66(0.54$ to 0.81$)$ & $0.85(0.67$ to 1.08$)$ & 1.29 & 1.02 to 1.58 \\
\hline
\end{tabular}

${ }^{*}$ Rate ratio of yearly exacerbations: $<1$ favours the alternative; $>1$ favours ICS, except Bhatt et al where \% reduction in exacerbations versus placebo was reported.

†Fluticasone furoate/vilanterol versus placebo, no difference was seen for fluticasone furoate versus placebo or vilanterol versus placebo. ICS, inhaled corticosteroids. 
et al were multicentre studies which compared fluticasone furoate/vilanterol (ICS/LABA) to vilanterol (LABA) or placebo. Each study classified smoking status differently: Wedzicha $e t$ al, Bhatt et al and Pascoe et al classified participants as a current smoker or ex-smoker. Hinds et al classified them by pack-years smoked; $\leq 46$ pack-years or $>46$ pack-years thus making direct comparison between the results difficult. In total there were 27460 participants.

The additional study not included in this systematic review, Bafadhel et al (2018), reported that smoking status was a predictor of response to budesonide/formoterol in reducing exacerbations; ex-smokers had a lower exacerbation ratio (vs formoterol alone) than current smokers. ${ }^{15}$ However, the results were stratified by eosinophil count and the data could not be extracted to make a meaningful comparison to the other RCTs discussed here.

All four studies reported that current or heavier smokers in the ICS treatment arm were associated with a higher exacerbation rate than ex-smokers or lighter smokers. One study reported that LABA alone was less effective at reducing yearly exacerbation rates than ICS/ LABA if pack-year history is equal to, or less than 46 (RR $1.29 ; 5 \%$ CI 1.02 to 1.58$).{ }^{20}$ But LABA alone was more effective if pack years $>46$ (RR $0.81 ; 95 \%$ CI 0.63 to 1.06), however this result was not statistically significant. Two studies reported that overall, participants who were current smokers in the ICS treatment arm had less favourable outcomes in terms of exacerbations (RR 0.83 and $0.99 ; 95 \%$ CI 0.74 to 0.92 and 0.87 to 1.12 ) than ex-smokers (RR 0.92 and $1.20 ; 95 \%$ CI 0.83 to 1.01 and 1.10 to 1.33$).{ }^{1923}$ The final study showed that exacerbation rates were reduced with ICS/LABA versus placebo and that this effect was greater in ex-smokers than current smokers $(36 \%$ vs $19 \%, \mathrm{p}=0.013){ }^{21}$

\section{QUALITY ASSESSMENT}

Each of the seven included studies (plus the excluded study by Hoonhorst et al) were assessed using the Cochrane Collaboration's tool for assessing the risk of bias (figure 2). Overall the quality of all included trials was high, however the main limitation was lack of information on how the random allocation was made and how this was concealed. Several trials had other sources of bias; although randomisation was undertaken in the original trial, the post hoc analyses reported in this systematic review used a subset of the original participants and therefore it cannot be determined if the original randomisation process holds. In addition, Hoonhorst (2014) and Snoeck-Stroband (2015) were powered to detect change in CD8 count, not lung function. Only 114 patients were recruited in the parent trial and it is unlikely that these were sufficiently powered to detect a change in lung function. Bhatt $e t$ al was a prespecified secondary analysis of the SUMMIT study, the results were published as a 'letter to the editor' in a shortened version of a full paper. The original SUMMIT trial was peer-reviewed and thus the

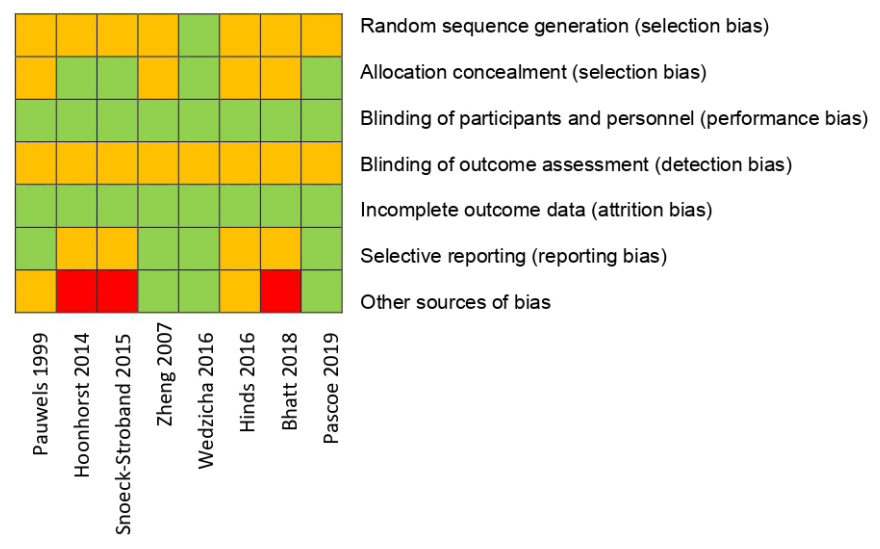

Figure 2 Quality assessment of included studies using Cochrane Collaboration tool for assessing risk of bias. Red=high risk of bias; amber=uncertain/cannot tell; green=low risk of bias.

results were included in this systematic review due to the robustness of the original data and significant number of participants it included.

\section{DISCUSSION}

Heavier smokers, with a greater pack-year history, were less likely to benefit from ICS use in terms of lung function and yearly exacerbation rates than those who were lighter smokers. When categorised in terms of smoking status, that is, smoker or ex-smoker, the majority of participants who were ex-smokers showed a greater increase in lung function and decrease in exacerbations over current smokers with ICS use. No definitive conclusions can be drawn from these data due to the lack of statistical significance reporting for most of the results and differences in stratification of smoking status and measurement of lung function. For generalisability of results, the participants had a wide range of severity of COPD, however the most severely affected $\left(\mathrm{FEV}_{1}<30 \%\right.$ predicted) were underrepresented. In addition, although changes in lung function and exacerbation rates were found, the magnitude of these changes are unlikely to be clinically significant.

In the studies that stratified participants by pack years smoked, dividing participants into groups of $>/ \leq 36$ pack years or $>/ \leq 42$ pack years was not justified; there were no documented reason why these divisions were set but may be because this was a post hoc analysis of the results and the original participants were not stratified according to smoking status. Furthermore, in most studies smoking status was self-reported by the participants at the beginning of the study. There was no objective measure used and change in smoking status through the study was not accounted for.

\section{Effect on lung function}

The effect of smoking on outcomes from ICS use on lung function were mixed and depended on how smoking was defined. The decline in $\mathrm{FEV}_{1}$ found in the trials stratifying smoking by pack-years ranged from $22 \mathrm{~mL} /$ year to 
$75 \mathrm{~mL} /$ year; implying that a greater number of pack years smoked resulted in a greater decline in lung function. By comparison, the trials that stratified by current smoking status found mixed results.

Of the studies that stratified by pack years smoked, the largest study (Pauwels et al) showed that those with $>36$ pack years receiving ICS had an $\mathrm{FEV}_{1}$ decline of $50 \mathrm{~mL} /$ year (median slope of $\mathrm{FEV}_{1}$ used) over those with a lighter smoking history at 6 months. In the longer term, Pauwels et al again reported a greater decline in lung function at 36 months in heavier smokers using ICS than lighter smokers, although by a reduced amount $(22 \mathrm{~mL} /$ year $)$. Snoeck-Stroband et al also found a similar result $(75 \mathrm{~mL} /$ year decline, $\mathrm{p}=0.023$ ), however was a very small study and a high risk of bias in the way participants were selected from the original trial.

Of the studies that stratified by smoking status, the smallest study (Zheng et al) reported a decline in $\mathrm{FEV}_{1}$ in non-smokers in comparison to ex-smokers or current smokers. The remaining, largest study by Bhatt et al accounted for over 16000 participants and reported the opposite result; ex-smokers receiving ICS had less decline in lung function than smokers $(8 \mathrm{~mL})$. Although this result was statistically significant it is not clinically important. The excluded study by Hoonhorst $e t$ al also showed that ex-smokers had less decline in lung function at 30 months. However, the size of the study and the original reporting of $\mathrm{FEV}_{1}$ in litres to only two significant figures make these results unreliable and imprecise. Furthermore, the lung function of smokers receiving placebo increased from baseline to 6 months; a result that is inconsistent with the wealth of literature on effects of smoking.

\section{Effect on exacerbations}

A clearer result was seen for effect on exacerbations; all studies reported a lesser decrease in yearly exacerbation rates when ICS was given to heavy or current smokers versus ex-smokers and lighter smokers; implying that ICS are less effective in heavier smokers. In addition, the large participant numbers and reporting of CIs makes us more certain that these are true results. However, in each set of results the $95 \%$ CI of the rate ratio crosses the threshold of one, making it possible that there is no difference between the comparison groups.

It was expected that smoking with ICS use would show a clearer impact on exacerbation rates than lung function; ICS are already known to have a larger impact on reducing rates of exacerbations than in slowing the decline of lung function. ${ }^{26}$ However it should be noted that in Wedzicha et al the effect of ICS/LABA was less than the alternative treatment of LAMA/LABA which may suggest ICS are of more limited efficacy in reducing exacerbation rates than other inhaled therapies, regardless of smoking status.

The outcome of this systematic review is consistent with the literature, indicating that steroid resistance of smokers to the effects of ICS may be present. ${ }^{10-12} 2728$ However, just as there is uncertainty in the literature as to whether smoking cessation reverses this resistance, ${ }^{13} 14$ there is uncertainty here as to if smoking status effects outcomes with ICS. More work is needed to determine the pack-year quantity at which it would be expected that smoking would cause steroid resistance and if smoking cessation reduces steroid resistance. Furthermore, studies that report effect of smoking as a primary outcome and are adequately powered to detect this are needed. For now, clinicians should be aware that patients who are heavier smokers or current smokers may not respond as expected to ICS and that other inhaled therapies may be more beneficial.

\section{CONCLUSION}

In COPD, current or heavy smokers (over 36 pack years) may not gain the same benefit from ICS use on lung function and exacerbation rates as lighter or ex-smokers do. This could be due to 'steroid resistance' caused by smoking, or other factors, such as difference in; severity of disease, co-prescribed medicines (such as bronchodilators) and methodology between trials. In practice this means that practitioners should consider smoking status before prescribing ICS due to potentially reduced efficacy; however further work is needed with greater patient numbers to determine if there is an effect of 'steroid resistance' in current smokers.

Contributors KS (c0-author): Agreed the search strategy, agreed the papers for inclusion, extracted data from the papers, analysed the results, wrote this systematic review. HA (co-author): Prepared the search strategy, identified the papers for inclusion, extracted data from the papers. RK (co-author): Reviewed the analysis of the systematic review and reviewed the writing of this paper.

Funding This work was supported by Pharmacy Research UK grant number PRUK-2017-PA1-A.

Competing interests None declared.

Patient and public involvement Patients and/or the public were not involved in the design, or conduct, or reporting or dissemination plans of this research.

Patient consent for publication Not required.

Provenance and peer review Not commissioned; externally peer reviewed.

Data availability statement Data are available in a public, open access repository. All data relevant to the study are included in the article or uploaded as supplementary information. Extra data can be accessed via the Dryad data repository at https://datadryad.org/stash, doi:10.5061/dryad.3j9kd51ds.

Open access This is an open access article distributed in accordance with the Creative Commons Attribution Non Commercial (CC BY-NC 4.0) license, which permits others to distribute, remix, adapt, build upon this work non-commercially, and license their derivative works on different terms, provided the original work is properly cited, appropriate credit is given, any changes made indicated, and the use is non-commercial. See: http://creativecommons.org/licenses/by-nc/4.0/.

\section{ORCID iD}

Kimberley Sonnex http://orcid.org/0000-0001-6799-8985

\section{REFERENCES}

1 Lamprecht B, McBurnie MA, Vollmer WM, et al. Copd in never smokers: results from the population-based burden of obstructive lung disease study. Chest 2011;139:752-63.

2 Schneider C, Bothner U, Jick SS, et al. Chronic obstructive pulmonary disease and the risk of cardiovascular diseases. Eur $J$ Epidemiol 2010;25:253-60. 
3 Anthonisen NR, Connett JE, Murray RP. Smoking and lung function of lung health study participants after 11 years. Am J Respir Crit Care Med 2002;166:675-9.

4 Barnes PJ, Ito K, Adcock IM. Corticosteroid resistance in chronic obstructive pulmonary disease: inactivation of histone deacetylase. Lancet 2004;363:731-3.

5 Thomson NC, Spears M. The influence of smoking on the treatment response in patients with asthma. Curr Opin Allergy Clin Immunol 2005;5:57-63.

6 Chronic Obstructive Pulmonary Disease. Management of chronic obstructive pulmonary disease in adults in primary and secondary care. London: National Clinical Guideline Centre - Acute and Chronic Conditions, 2010.

7 Vestbo J, Hurd SS, Agustí AG, et al. Global strategy for the diagnosis, management, and prevention of chronic obstructive pulmonary disease: gold executive summary. Am J Respir Crit Care Med 2013;187:347-65.

8 Barnes PJ. Inhaled corticosteroids in COPD: a controversy. Respiration 2010;80:89-95.

9 Suissa S, Barnes PJ. Inhaled corticosteroids in COPD: the case against. Eur Respir J 2009;34:13-16.

10 Culpitt SV, Rogers DF, Shah P, et al. Impaired inhibition by dexamethasone of cytokine release by alveolar macrophages from patients with chronic obstructive pulmonary disease. Am J Respir Crit Care Med 2003;167:24-31.

11 Marwick JA, Caramori G, Stevenson CS, et al. Inhibition of PI3Kdelta restores glucocorticoid function in smoking-induced airway inflammation in mice. Am J Respir Crit Care Med 2009;179:542-8.

12 Ito K, Hanazawa T, Tomita K, et al. Oxidative stress reduces histone deacetylase 2 activity and enhances IL-8 gene expression: role of tyrosine nitration. Biochem Biophys Res Commun 2004;315:240-5.

13 Gamble E, Grootendorst DC, Hattotuwa K, et al. Airway mucosal inflammation in COPD is similar in smokers and ex-smokers: a pooled analysis. Eur Respir J 2007;30:467-71.

14 Invernizzi G, Ruprecht A, De Marco C, et al. Inhaled steroid/tobacco smoke particle interactions: a new light on steroid resistance. Respir Res 2009:10:48.

15 Bafadhel M, Peterson S, De Blas MA, et al. Predictors of exacerbation risk and response to budesonide in patients with chronic obstructive pulmonary disease: a post-hoc analysis of three randomised trials. Lancet Respir Med 2018;6:117-26.

16 Hoonhorst SJM, ten Hacken NHT, Vonk JM, et al. Steroid resistance in COPD? overlap and differential anti-inflammatory effects in smokers and ex-smokers. PLoS One 2014;9:e87443.

17 Lapperre TS, Snoeck-Stroband JB, Gosman MME, et al. Effect of fluticasone with and without salmeterol on pulmonary outcomes in chronic obstructive pulmonary disease: a randomized trial. Ann Intern Med 2009;151:517-27.

18 Snoeck-Stroband JB, Lapperre TS, Sterk PJ, et al. Prediction of long-term benefits of inhaled steroids by phenotypic markers in moderate-to-severe COPD: a randomized controlled trial. PLoS One 2015;10:e0143793.

19 Pascoe S, Barnes N, Brusselle G, et al. Blood eosinophils and treatment response with triple and dual combination therapy in chronic obstructive pulmonary disease: analysis of the impact trial. Lancet Respir Med 2019;7:745-56.

20 Hinds DR, DiSantostefano RL, Le HV, et al. Identification of responders to inhaled corticosteroids in a chronic obstructive pulmonary disease population using cluster analysis. BMJ Open 2016;6:e010099.

21 Bhatt SP, Anderson JA, Brook RD, et al. Cigarette smoking and response to inhaled corticosteroids in COPD. Eur Respir J 2018;51:1701393.

22 Zheng J-P, Yang L, Wu YM, et al. The efficacy and safety of combination salmeterol (50 microg)/fluticasone propionate (500 microg) inhalation twice daily via accuhaler in Chinese patients with COPD. Chest 2007;132:1756-63.

23 Wedzicha JA, Banerji D, Chapman KR, et al. IndacaterolGlycopyrronium versus Salmeterol-Fluticasone for COPD. N Engl J Med 2016;374:2222-34.

24 Pauwels RA, Löfdahl CG, Laitinen LA, et al. Long-Term treatment with inhaled budesonide in persons with mild chronic obstructive pulmonary disease who continue smoking. European respiratory Society study on chronic obstructive pulmonary disease. $N$ Engl J Med 1999;340:1948-53.

25 Dransfield MT, Bourbeau J, Jones PW, et al. Once-Daily inhaled fluticasone furoate and vilanterol versus vilanterol only for prevention of exacerbations of COPD: two replicate double-blind, parallel-group randomised controlled trials. Lancet Respir Med 2013;1:210-23.

26 Burge PS, Calverley PM, Jones PW, et al. Randomised, double blind, placebo controlled study of fluticasone propionate in patients with moderate to severe chronic obstructive pulmonary disease: the ISOLDE trial. BMJ 2000;320:1297-303.

27 Irusen E, Matthews JG, Takahashi A, et al. P38 mitogen-activated protein kinase-induced glucocorticoid receptor phosphorylation reduces its activity: role in steroid-insensitive asthma. J Allergy Clin Immunol 2002;109:649-57.

28 Nowak D, Kasielski M, Antczak A, et al. Increased content of thiobarbituric acid-reactive substances and hydrogen peroxide in the expired breath condensate of patients with stable chronic obstructive pulmonary disease: no significant effect of cigarette smoking. Respir Med 1999;93:389-96. 